\title{
Low amplitude pulse electric field for elimination of unpleasant sensation associated with high amplitude electric field for electrochemotherapy
}

\author{
Hassan Buhari Mamman ${ }^{1}$, Muhammad Mahadi Abdul Jamil ${ }^{2 *}$, Mohamad Nazib Adon ${ }^{3}$ \\ 1, 2, 3 Department of Electrical and Electronics Engineering, Universiti Tun Hussein Onn Malaysia, Johor, Malaysia
}

\author{
Index Terms \\ Electroporation \\ Electric Field \\ Electrochemotherapy \\ Permeabilization \\ Cell Attachment \\ Cell Proliferation
}

Received: 7 October 2016

Accepted: 10 February 2017

Published: 21 April 2017

\begin{abstract}
Electrochemotherapy is a combined use of a chemotherapeutic drug and short intense electric field for cancer treatment. The applied electric field increases the permeability of the cell membrane thereby increasing the free entrance of the drug into the cancer cell for effective treatment at minimal drug dose. However, patients undergoing electrochemotherapy in clinical trial complain of unpleasant sensation due to muscle contraction during the pulse delivery (usually $1000 \mathrm{~V} / \mathrm{cm}, 100 \mu \mathrm{s}$, and 8 numbers of pulses). This unpleasant sensation is caused because of the high amplitude of pulse or due to the low repetition frequency of the pulse $(1 \mathrm{~Hz})$. Hence, in this paper, a low voltage amplitude $(600 \mathrm{~V} / \mathrm{cm})$ electric pulse at relatively higher pulse durations ranging from $500 \mu$ s to $20 \mathrm{~ms}$ was used in electroporating cells in vitro. The percentage of cell permeabilization and viability of the different pulse durations were measured. The result revealed that $500 \mu$ s duration stimulates the cell proliferation and $20 \mathrm{~ms}$ result in $90 \%$ of cell death. On the other hand $5 \mathrm{~ms}$ pulse duration resulted in $65 \%$ permeabilization and $80 \%$ viability. Hence the study suggested that $600 \mathrm{~V} / \mathrm{cm}$ at $5 \mathrm{~ms}$ duration can be used for electrochemotherapy to potentially eliminate the unpleasant sensation associated with high amplitude pulse.
\end{abstract}

(c) 2017 The Author(s). Published by TAF Publishing.

\section{INTRODUCTION}

Exposing biological cells to a high electric field of short duration induces an extra potential on the cell membrane, which superimposes on the membrane resting voltage that is continuously under physiological conditions [1]. The resting membrane potential has a value in the range of $-40 \mathrm{mV}$ to $-80 \mathrm{mV}$ depending on the cell type, size, and composition [2-4]. However, if the induced potential reaches a threshold value of $0.2-1 \mathrm{~V}$, a localized structural rearrangement of lipid bilayer occurrs [5]. This results in formation of nanopores in the cell membrane and hence, increases the membrane permeability and conductivity [6]. Thus, molecules that are otherwise impermeable to membrane can easily enter into the membrane. This process is electropermeabilization or electroporation [7-9]. Ever since its discovery, electroporation has been used effectively for numerous applications in biotechnology and biomedical en- gineering. These applications include but not limited to gene therapy [10-11], electrochemotherapy (ECT) [12-15], electro-fusion [16-17], electro-sterilization [18] and tumor tissue ablation [19-20]. Among these applications, electrochemotherapy is progressing much more and now it has reached pre-clinical and clinical trials [21].

The use of chemotherapeutic drugs joined together with electroporation is called electrochemotherapy. Electrochemotherapy facilitates the delivery of chemotherapeutic drugs to malignant cell [22]. Many chemotherapeutic drugs cannot cross the cell membrane under normal condition. Therefore, with the help of electrochemotherapy, this can easily be achieved by creating pores in the cell membrane by the use of an electric field [22]. Commonly used drugs for chemotherapy such as bleomycin and cisplatin were found to be much more effective in the electrochemotherapy than in only chemotherapy when applied

\footnotetext{
${ }^{*}$ Corresponding author: Muhammad Mahadi Abdul Jamil

†Email: mahadi@uthm.edu.my
} 
to the tumor cell lines both in vitro and in vivo [23-24] with reduction in drug dose and side effect. Despite the increase in the number of preclinical and clinical trials on electrochemotherapy, many questions regarding the therapy are still open. For instance, determination of electric field parameter would guarantee a treatment that is successful with a negligible side effect.

Eight pulses of $100 \mu$ s duration with a field strength of $1000 \mathrm{~V} / \mathrm{cm}$ at a repetition frequency of $1 \mathrm{~Hz}$ has been employed as a standard electric field parameter for electrochemotherapy in both pre-clinical and clinical trials [25]. The efficiency of these parameters was first reported by [26] based on the outcome of an in vitro experiment [27]. Same parameters resulted in optimal condition when used in vivo $[21,28]$. Since then, these parameters have been employed as the standard parameter for electrochemotherapy. However, patients undergoing electrochemotherapy complain of transient burns in the area that is in contact with electrode [29] plus muscular contraction that are unpleasant [30]. These unpleasant sensations and burns are caused due to the high amplitude electric field or low repetition frequency of the pulse [31].

Hence, in this paper, a low amplitude electric field fixed at an amplitude of $600 \mathrm{~V} / \mathrm{cm}$ and pulse durations equal to or greater than the pulse duration of standard electric parameters for ECT would be employed. This was done to check for a value that results in a similar efficiency of electroporation with the standard electric parameter (8 pulses of $100 \mu$ s duration at a repetition frequency of $1 \mathrm{~Hz}$ and field strength of $1000 \mathrm{~V} / \mathrm{cm}$ ) in terms of viability and percentage permeabilization, at reduced pulse amplitude. The reduced pulse amplitude, $600 \mathrm{~V} / \mathrm{cm}$, could, therefore, decrease or eliminate the unpleasant sensation associated with high amplitude pulse.

\section{MATERIALS AND METHODS}

\section{A. Cell Culture}

In this study, the HT29 cell lines were used for the experiments. The colon cell lines were cultured as a monolayer in a $25 \mathrm{~cm} 2$ culture flask. Complete growth media used were RPMI1640 enriched with $10 \%$ fetal bovine serum (FBS) and 1\% antibiotic (penicillin and streptomycin) which are all products of Gibco USA. The cells were cultured in a humidified incubator at $37 \circ \mathrm{C}$, containing $5 \%$ $\mathrm{CO}_{2}$ [32-33]. Cells were sub-cultured every 3 to 5 days whenever they reached $80 \%$ to $90 \%$ confluent [32].

\section{B. Cell Detachment or Cell Trypsinization}

For cell trypsinization, the old medium was aspirated and discarded. Afterward, $3 \mathrm{ml}$ of phosphate buffer saline (PBS) was added to wash the cells [33]. The added PBS was aspirated and discarded. Subsequently, $2 \mathrm{ml}$ of the Tryple Express solution was added in order to disassociate the cells from the substrate [33].

The Flask containing the cells and the Tryple Express was incubated for $5-10$ minutes at $5 \% \mathrm{CO} 2$ at $37^{\circ} \mathrm{C}$. This is because the tryple express works well in a warm environment. When the cells were fully detached, an equal volume of complete growth medium was added to stop the effect of the tryple express (neutralization).

\section{Electroporation Protocol}

After detaching the cells with tryple express and neutralizing with an equal volume of complete growth medium, cell counted with a hemocytometer and resuspended to a concentration of $9.8 \times 10^{5}$ cells $/ \mathrm{ml}$. For cell viability measurement, $600 \mu \mathrm{l}$ of cells suspension, at a concentration of $9.8 \times 10^{5}$ cells $/ \mathrm{ml}$, were then poured into six (6) $4 \mathrm{~mm}$ gap electrode cuvette (BTX Harvard Apparatus). A single pulse Electric field with amplitude of $600 \mathrm{~V} / \mathrm{cm}$ (i.e. a voltage $240 \mathrm{~V}$ for a $4 \mathrm{~mm}$ gap electrode cuvette) and different pulse duration ranging from $100 \mathrm{us}$ to $20 \mathrm{~ms}$ (that is, $100 \mu \mathrm{s}, 500 \mu \mathrm{s}$, $5 \mathrm{~ms}, 10 \mathrm{~ms}$ and $20 \mathrm{~ms}$ ) were used in electroporating the cells in five different cuvettes, one duration for each cuvette.

Another cuvette was electroporated with the standard electric field parameter $(1000 \mathrm{~V} / \mathrm{cm}, 100 \mu \mathrm{s}$ duration, 8 pulses and repetition frequency of $1 \mathrm{~Hz}$ ) as a positive control. Subsequently, a $300 \mu$ l of cell suspension (representing 294,000 cells) from each cuvette, were then seeded into wells of six-well culture flasks containing $2 \mathrm{ml}$ of complete growth medium. The cells were then incubated at $37 \mathrm{oC}$ and $5 \%$ of $\mathrm{CO}_{2}$. Similarly, 294,000 cells, from the same initial flask but without electroporation, were seeded in another well containing $2 \mathrm{ml}$ of complete growth medium as a negative control. Both flasks were kept under the same condition.

For determination of cell permeability, cells were first diluted with $100 \mu \mathrm{g} / \mathrm{ml}$ of propidium iodide (PI) in a ratio of $10: 1$ (that is $4.5 \mathrm{ml}$ of cell suspension to $0.5 \mathrm{ml}$ of PI). Thereafter, the same procedure for the determination of cell viability was followed. However, cells were incubated only for 5 minutes at room temperature after the electric treatment and subsequently, images were acquired using fluo- 
rescent microscopy and phase contrast microscopy, from different field view on the day of the experiment.

\section{Determination of Percentage Cell Permeabilization}

After exposing the mixture of cells and the PI to the different electric field parameters, the cells were incubated at room temperature for five minutes. The cells were then transferred to a top stage of an inverted microscope for imaging. Images were taken using both fluorescent microscopy using Nikon Ti-series inverted microscope. Additionally, a corresponding phase contrast image of the same field of view was acquired at the same time. Each experiment was repeated three times. Percentage permeability was measured by quantifying the penetration of PI into the cells. Cell percentage permeabilization was calculated by taking the ratio of a total number of permeabilized cells in a region of interest to the total number of cells in that field of view times $100 \%$.

\section{E. Determination of Percentage Cell Viability}

Cell viability was computed using trypan blue exclusion test with aid hemocytometer. After the electric treatment, cells were incubated at $37^{\circ} \mathrm{C}$ and $5 \%$ of $\mathrm{CO}_{2}$ for 24 hours. Afterward, cells were trypsinized and counted for viability. Percentage viability was calculated as a total number of viable cells in a region of interest, divided by the total number of cells (live plus a death in that region of interest) time 100

\section{RESULTS AND DISCUSSION}

Cell percentage permeabilizations were measured by counting the number of cells successfully penetrated by PI in a region of interest to the total number of cells in that region with the help of fluorescent microscopy. Fluorescent images and their corresponding phase contrast images were acquired using a 20X objective microscope. The photomicrograph of images was shown in figure 1 . The mean percentage permeabilization with standard deviation (SD) for three replicate experiments was given in Table 1 and figure 2. At a fixed pulse duration of $600 \mathrm{~V} / \mathrm{cm}$ with single pulse, $100 \mu \mathrm{s}, 500 \mu \mathrm{s}, 5 \mathrm{~ms}, 10 \mathrm{~ms}$ and $20 \mathrm{~ms}$ revealed $5.2 \%$ $\pm 2.2 \mathrm{SD}, 36.3 \% \pm 4.7 \mathrm{SD}, 70.3 \% \pm 2.3 \mathrm{SD}, 78.0 \% \pm 2.4 \mathrm{SD}$ and $88.7 \% \pm 5.7 \mathrm{SD}$ percentage permeability respectively. The negative control group revealed a $1 \% \pm 0.1 \mathrm{SD}$ permeability while the positive control revealed $80.2 \% \pm 3$.2SD perme- ability. Percentage permeability was found to increase with an increase in pulse duration from $100 \mu$ s to $20 \mathrm{~ms}$ at constant pulse amplitude $(600 \mathrm{~V} / \mathrm{cm})$ and one pulse (1).
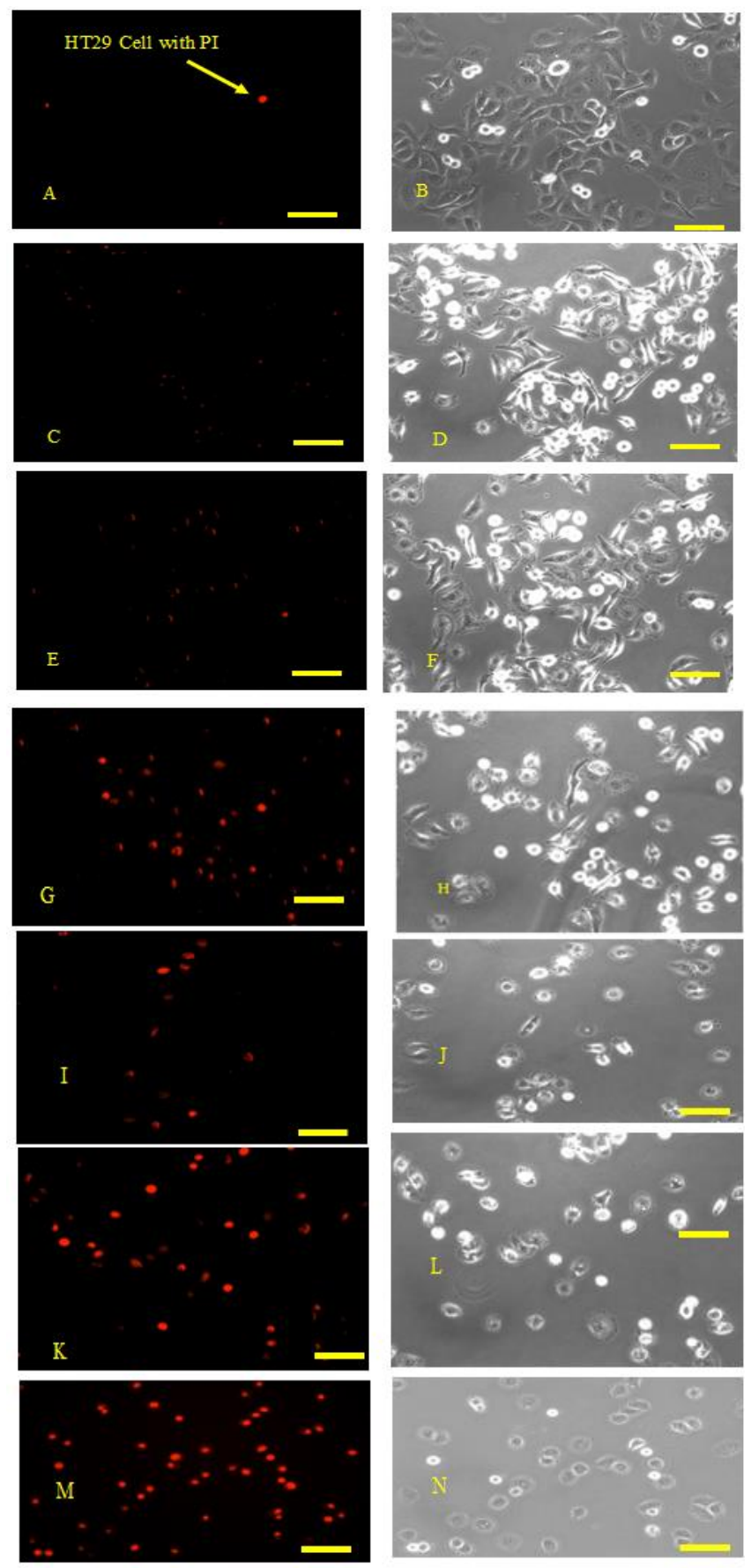

Fig. 1. (A - M): Photomicrograph of fluorescent and phase contrast images of HT29 cell line after electroporation;

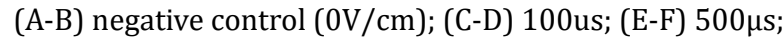
(G-H) 5ms; (I-J)10ms; (K-L)20ms (M-N) standard parameter for ECT. 
TABLE 1

MEAN PERCENTAGE PERMEABILITY OF HT29 CELL LINE AFTER ELECTROPORATION WITH DIFFERENT ELECTRIC FIELD PARAMETERS $(\mathrm{N}=3)$

\begin{tabular}{lc}
\hline \hline Electric Field Parameter & Percentage Permeability $(\%) \pm$ SD \\
\hline Control $(0 \mathrm{~V} / \mathrm{cm})$ & $1 \pm 0.1$ \\
$100 \mu \mathrm{s}, 600 \mathrm{~V} / \mathrm{cm}$ & $5.2 \pm 2.2$ \\
$500 \mu \mathrm{s}, 600 \mathrm{~V} / \mathrm{cm}$ & $36.3 \pm 4.7$ \\
$5 \mathrm{~ms}, 600 \mathrm{~V} / \mathrm{cm}$ & $70.3 \pm 2.3$ \\
$10 \mathrm{~ms}, 600 \mathrm{~V} / \mathrm{cm}$ & $78.0 \pm 2.4$ \\
$20 \mathrm{~ms}, 600 \mathrm{~V} / \mathrm{cm}$ & $88.7 \pm 5.7$ \\
Standard parameter for ECT & $80.2 \pm 3.2$ \\
\hline \hline
\end{tabular}

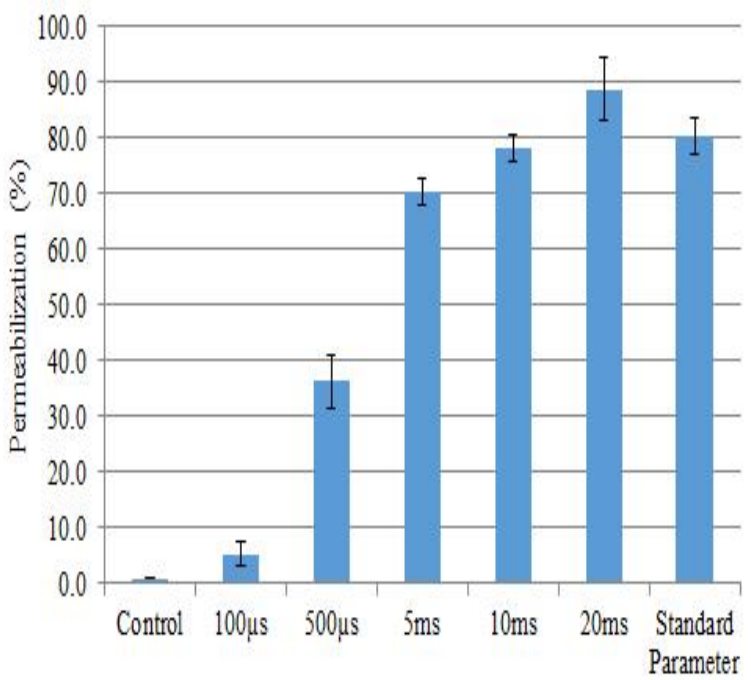

Fig. 2 . Mean Percentage Permeability of HT29 Cell Line after Electroporation with different Electric Field Parameters. $(\mathrm{N}=3)$. Standard deviation is used as error bars $(\mathrm{n}=3)$

Cell viability was counted using trypan blue exclusion test with aid of a hemocytometer 24 hours after the electric treatment (electroporation). Figure 3 shows a photomicrograph from one field of view, one for each treatment from several acquired fields of view during viability counting. The mean percentage viability with standard deviation (SD) for three replicate experiments was given in Table 2 and figure 4 . At a fixed pulse duration of $600 \mathrm{~V} / \mathrm{cm}$ with single pulse, $100 \mu \mathrm{s}, 500 \mu \mathrm{s}, 5 \mathrm{~ms}, 10 \mathrm{~ms}$ and $20 \mathrm{~ms}$ revealed $86.1 \% \pm 2.2$ SD, $94.3 \% \pm 2.6 \mathrm{SD}, 80.4 \% \pm 3.0 \mathrm{SD}, 55.0 \%$ $\pm 4.0 \mathrm{SD}$ and $23.0 \% \pm 3.4 \mathrm{SD}$ viability respectively. The negative control group revealed a $90.3 \% \pm 1.8 \mathrm{SD}$ viability while the positive control revealed $91.5 \% \pm 5.1$ SD viability. Percentage viability was found to decrease with increase in pulse duration from $500 \mu$ s to $20 \mathrm{~ms}$ at constant pulse amplitude $(600 \mathrm{~V} / \mathrm{cm})$ and one pulse (1).
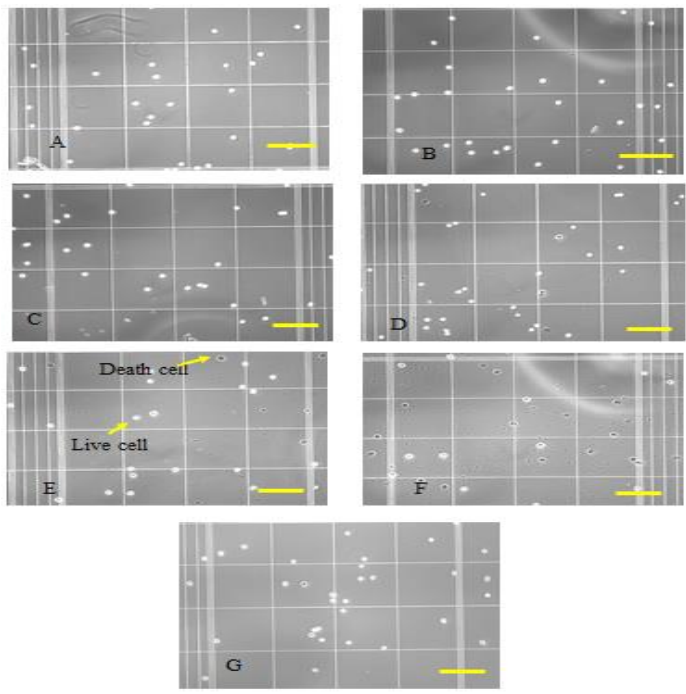

Fig. 3 . Mean Percentage Permeability of HT29 Cell Line after Electroporation with different Electric Field Parameters. $(\mathrm{N}=3)$. Standard deviation is used as error bars $(\mathrm{n}=3)$

TABLE 2

MEAN PERCENTAGE VIABILITY OF HT29 CELL LINE, 24 HOURS AFTER ELECTROPORATION WITH DIFFERENT ELECTRIC FIELD PARAMETERS (N=3)

\begin{tabular}{lc}
\hline \hline Electric field parameter & Percentage viability $(\%) \pm \mathrm{SD}$ \\
\hline Control $(0 \mathrm{~V} / \mathrm{cm})$ & $90.3 \pm 1.8$ \\
$100 \mu \mathrm{s}, 600 \mathrm{~V} / \mathrm{cm}$ & $86.1 \pm 2.2$ \\
$500 \mu \mathrm{s}, 600 \mathrm{~V} / \mathrm{cm}$ & $94.3 \pm 2.6$ \\
$5 \mathrm{~ms}, 600 \mathrm{~V} / \mathrm{cm}$ & $80.4 \pm 3.0$ \\
$10 \mathrm{~ms}, 600 \mathrm{~V} / \mathrm{cm}$ & $55.0 \pm 4.0$ \\
$20 \mathrm{~ms}, 600 \mathrm{~V} / \mathrm{cm}$ & $23.0 \pm 3.4$ \\
Standard parameter for ECT & $91.5 \pm 5.1$ \\
\hline \hline
\end{tabular}

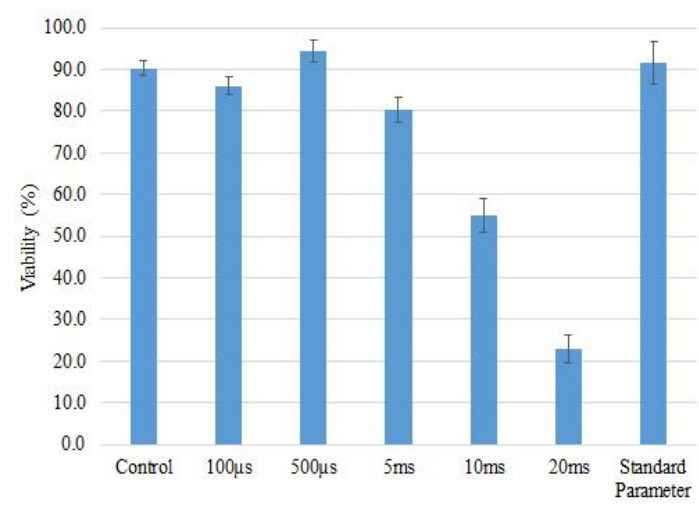

Fig. 4. Mean Percentage Viability of HT29 Cell Line, 24 hours after Electroporation with different Electric Field Parameters. $(\mathrm{N}=3)$. Standard deviation is used as error bars $(\mathrm{N}=3)$ 
In this paper, attention was given to the effect of pulse duration on cell viability and permeability of the cell membrane. Pulse amplitude was fixed at $600 \mathrm{~V} / \mathrm{cm}$ and the number of the pulses was fixed to one. The standard electric parameter for electrochemotherapy was used as positive control while non-electroporated cells were used as negative control.

The cell's viability and permeability dependence on the pulse duration were measured using five pulses durations (that is $100 \mathrm{us}, 500 \mathrm{us}, 5 \mathrm{~ms}, 10 \mathrm{~ms}$, and $20 \mathrm{~ms}$ ). Cell's viability was found to decrease with increase in pulse duration at constant pulse amplitude [34]. Whereas, permeability was found to be proportional to pulse duration (that is, permeability increases with an increase in pulse duration from 100 us to $20 \mathrm{~ms}$ ), with constant pulse amplitude and the number of a pulse $[35,36]$.

This result of this study is in agreement with that of $[6,2526]$. Among the parameters used, only $5 \mathrm{~ms}$ at a pulse amplitude of $600 \mathrm{~V} / \mathrm{cm}$ reveals relatively similar permeability and viability with Standard electric parameter. Hence, this low pulse amplitude could completely eradicate the muscular contraction and unpleasant sensation associated with high amplitude pulse during electrochemotherapy in vivo with the same efficiency.

\section{CONCLUSION}

The result in this paper revealed that pulse amplitude of $600 \mathrm{~V} / \mathrm{cm}$ with duration of $500 \mu$ s stimulated cellular proliferation while $20 \mathrm{~ms}$ duration resulted in more than $80 \%$ cell death. On the other hand, $5 \mathrm{~ms}$ pulse duration resulted to similar percentage of permeability and viability with the standard electric field parameter for electrochemotherapy. Hence, we can conclude that $600 \mathrm{~V} / \mathrm{cm}$ and $5 \mathrm{~ms}$ duration can be used to eliminate the muscular sensation felt during electrochemotherapy (using standard electric field parameters).

\section{ACKNOWLEDGEMENTS}

The authors wish to acknowledge the financial support of the Ministry of Education Malaysia through Fundamental Research Grant Scheme (FRGS) Phase 2/2014 VOT no. 1488. The technical and laboratory support by Universiti Tun Hussein Onn Malaysia (UTHM) is also duly acknowledged.

\section{REFERENCES}

[1] A. Zupanic and D. Miklavcic, "Optimization and numerical modeling in irreversible electroporation treatment planning," in Irreversible Electroporation. Berlin, Germany: Springer, 2010.

[2] T. Kotnik, P. Kramar, G. Pucihar, D. Miklavcic and M. Tarek, "Cell membrane electroporationPart 1: The phenomenon," IEEE Electrical Insulation Magazine, vol. 28, no. 5, pp. 14-23, 2012. DOI: $10.1109 /$ MEI.2012.6268438

[3] G. Pucihar, T. Kotnik, D. Miklavčič and J. Teissié, "Kinetics of transmembrane transport of small molecules into electropermeabilized cells," Biophysical Journal, vol. 95, no. 6, pp. 2837-2848, 2008.

DOI: $10.1529 /$ biophysj.108.135541

[4] T. Kotnik, G. Pucihar and D. Miklavcic, "Induced transmembrane voltage and its correlation with electroporation-mediated molecular transport," The Journal of Membrane Biology, vol. 236, no. 1, pp.

3- $\quad 13,2010$. DOI: $10.1007 / \mathrm{s} 00232-010-9279-9$

[5] A. Golberg and B. Rubinsky, "A statistical model for multidimensional irreversible electroporation cell death in tissue," Biomedical Engineering Online, vol. 9, no. 1, pp. 1-13, 2010.

DOI: $10.1186 / 1475-925 X-9-13$

[6] C. Faurie, M. Golzio, E. Phez, J. Teissié and M. Rols, "Electric field-induced cell membrane permeabilization and gene transfer: theory and experiments," Engineering in Life Sciences, vol. 5, no. 2, pp. 179-186, 2005.

DOI: $10.1002 /$ elsc.200420068

[7] D. Miklavcic and L. Towhidi, "Numerical study of the electroporation pulse shape effect on molecular uptake of biological cells," Radiology and Oncology, vol. 44, no. 1, pp. 34-41, 2010.

DOI: $10.2478 / v 10019-010-0002-3316$

[8] E. Neumann, "Membrane electroporation and direct gene transfer," Bioelectrochemistry and Bioenergetics, vol. 28, no. 1-2: pp. 247-267, 1992.

DOI: $10.1016 / 0302-4598(92) 80017-B$

[9] U. Zimmermann and J. Vienken,

"Electric field induced cell-to-cell fusion," The Journal Of Membrane Biology, vol. 67, no. 1, pp. 165-182, 1982. DOI: $10.1007 / \mathrm{BF} 01868659$

[10] M. Golzio, M. P. Rols and J. Teissie, "In vitro and in vivo electric field-mediated permeabilization, gene 
transfer, and expression," Method, vol. 33, no. 2, pp. 126-135, 2004. DOI: 10.1016/j.ymeth.2003.11.003

[11] P. Hojman, H. Gissel and J. Gehl, "Sensitive and precise regulation of haemoglobin after gene transfer of erythropoietin to muscle tissue using electroporation," Gene Therapy, vol. 14, no. 12, pp. 950-959, 2007. DOI: $10.1038 /$ sj.gt.3302951

[12] M. Kranjc, F. Bajd, I. Sersa, J. Woo and D. Miklavcic, "Ex vivo and in silico feasibility study of monitoring electric field distribution in tissue during electroporation based treatments," PLOS ONE, vol. 7, no. 9, pp. e45737, 2012.

DOI: $10.1371 /$ journal.pone.0045737

[13] G. Sersa, M. Cemazar and M. Snoj, "Electrochemotherapy of tumours," Current Oncology, vol. 16, no. 2, pp. 34-35, 2009.

[14] M. Snoj, Z. Rudolf, M. Cemazar, B. Jancar and G. Sersa, "Successful sphincter-saving treatment of anorectal malignant melanoma with electrochemother-

apy, local excision and adjuvant brachytherapy,"

Anti- $\quad$ Cancer Drugs, vol. 16, no. 3, pp. 345-348, 2005. DOI: $10.1097 / 00001813-200503000-00015$

[15] N. Tozon, V. Kodre, G. Sersa and M. Cemazar, "Effective treatment of perianal tumors in dogs with electrochemotherapy," Anticancer Research, vol. 25, pp. 839-946, 2005.

[16] P. Gaynor, N. Wells and B. Oback, "Couplet alignment and improved electrofusion by dielectrophoresis for a zona-free high-throughput cloned embryo production system," Medical and Biological Engineering and Computing, vol. 43, no. 1, pp. 150-154, 2005. DOI: $10.1007 / B F 02345137$

[17] R. Orentas, D. Schauer, Q. Bin and B. Johnson, "Electrofusion of a weakly immunogenic neuroblastoma with dendritic cells produces a tumor vaccine," Cellular Immunology, vol. 213, no. 1, pp. 4-13, 2001. DOI: $10.1006 /$ cimm.2001.1864

[18] B. Rubinsky, "Irreversible electroporation in medicine," Technology in Cancer Research \& Treatment, vol. 6, no. 4, pp. 255-260, 2007.

DOI: $10.1177 / 153303460700600401$

[19] E. Lee, C. Loh and S. Kee, "Imaging guided percutaneous irreversible electroporation: Ultrasound and immunohistological correlation," Technology in Cancer Research \& Treatment, vol. 6, no. 4, pp. 287- 293, 2007 . DoI: $10.1177 / 153303460700600404$

[20] B. Rubinsky, G. Onik and P. Mikus, "Irreversible electroporation: A new ablation modality-Clinical implications," Technology in Cancer Research \& Treatment, vol. 6, no. 1, pp. 37-48, 2007.

DOI: $10.1177 / 153303460700600106$

[21] G. Sersa, T. Cufer, M. Cemazar, D. Miklavcic, M. Rebersek and Z. Rudolf, "Electrochemotherapy with bleomycin in the treatment of hypernephroma metastasis: Case report and literature review," Tumori, vol. 86, no. 2, pp. 163-165, 2000.

[22] N. Pavselj and D. Miklavcic, "Numerical modeling in electroporation-based biomedical applications," $R a$ diology and Oncology, vol. 42, no. 3, pp. 159-168, 2008. DOI: $10.2478 / v 10019-008-0008-2$

[23] L. M. Mir, J. Gehl, G. Sersa, C. G. Collins, J. R. Garbay, V. Billard and M. Marty, "Standard operating procedures of the electrochemotherapy," European Journal of Cancer Supplements, vol. 4, no. 11, pp. 1425, 2006. DOI: 10.1016/j.ejcsup.2006.08.003

[24] G. Sersa, M. Cemazar and M. Snoj, "Electrochemotherapy of tumours," Current Oncology, vol. 16, no. 2, pp. 34-35, 2009.

[25] A. Lebar, G. Sersa, S. Kranjc, A. Groselj and D. Miklavcic, "Optimisation of pulse parameters in vitro for in vivo electrochemotherapy," Anticancer Research, vol. 22, no. 3, pp. 1731-1736, 2002.

[26] L. Mir, S. Orlowski, J. Belehradek and C. Paoletti, "Electrochemotherapy potentiation of antitumour effect of bleomycin by local electric pulses," European Journal of Cancer And Clinical Oncology, vol. 27, no. 1, pp. 68-72, 1991.

DOI: $10.1016 / 0277-5379(91) 90064-\mathrm{K}$

[27] S. Orlowski, J. Belehradek, C. Paoletti and L. Mir, "Transient electropermeabilization of cells in culture," Biochemical Pharmacology, 37, no. 24, pp. 47274733, 1988. DOI: 10.1016/0006-2952(88)90344-9

[28] G. Sersa, B. Stabuc, M. Cemazar, D. Miklavcic and Z. Rudolf, "Electrochemotherapy with cisplatin: The systemic antitumour effectiveness of cisplatin can be potentiated locally by the application of electric pulses in the treatment of malignant melanoma skin metastases," Melanoma Research, vol. 10, no. 4, pp. 381-385, 2000.

DOI: $10.1097 / 00008390-200008000-00010$

[29] L. Mir and S. Orlowski, "Mechanisms of electrochemotherapy," Advanced Drug Delivery Reviews, vol. 35, no. 1, pp. 107-118, 1999.

DOI: $10.1016 / \mathrm{S} 0169-409 \mathrm{X}(98) 00066-0$

[30] L. Mir, L. Glass, G. Sersa, J. Teisssi, C. Domenge, 
D. Miklavcic,.... and M. Belehradek, "Effective treatment of cutaneous and subcutaneous malignant tumours by electrochemotherapy," British Journal of Cancer, vol. 77, no. 12, pp. 2336-2342, 1998.

DOI: $10.1038 /$ bjc.1998.388

[31] G. Pucihar, L. M. Mir and D. Miklavcic, "The effect of pulse repetition frequency on the uptake into electropermeabilized cells in vitro with possible applications in electrochemotherapy," Bioelectrochemistry, vol. 57, no. 2, pp. 167-172, 2002.

DOI: $10.1016 /$ S1567-5394(02)00116-0

[32] H. Mamman, A. Sadiq, M. Adon and M. Jamil, "Study of electroporation effect on HT29 cell migration properties," in IEEE International Conference on Control System, Computing And Engineering (ICCSCE), Penang, Malaysia, 2015,

DOI: $10.1109 /$ ICCSCE.2015.7482209

[33] V. Pehlivanova, I. Tsoneva and R. Tzoneva, "Multiple effects of electroporation on the adhesive behaviour of breast cancer cells and fibroblast," Cancer In- ternational, vol. 12, no. 9, pp. 1-9, 2012.

DOI: $10.1186 / 1475-2867-12-9$

[34] M. Mamman, M. Adon and M. Abdul Jamil, "Optimization of electric field parameters for HT29 cell line towards wound healing application," in 2nd International Conference on Science, Engineering and Social Science (ICSESS), Johor, Malaysia 2016.

[35] N. Semsri, C. Torasa, K. Samerjai, M. Suksombat and P. Sinpeng, "Electricity-generating wind turbine from electric bicycle motor," International Journal of Technology and Engineering Studies, vol. 2, no. 4, pp. 101- $\quad 109,2016$.

DOI: $10.20469 /$ ijtes.2.40002-4

[36] S. Muthucumaran. S. Pathmarajah and M. I. M. Mowjood, "Vertical variation of salinity, electrical conductivity, temperature and ph of batticaloa lagoon," International Journal of Applied and Physical Sciences, vol. 1, no. 2, pp. 36-41, 2015.

DOI: $10.20469 /$ ijaps.50003-2

— This article does not have any appendix. — 